\title{
Fusi Gen Translocation Ets Leukemia-Acute Myeloid Leukemia 1 [Tel-Aml1] Sebagai Faktor Prognosis pada Leukemia Limfoblastik Akut Anak
}

\author{
Sri Mulatsih ${ }^{1}$, Sunarto $^{1}$, Sutaryo ${ }^{1}$ \\ ${ }^{1}$ Bagian Ilmu Kesehatan Anak, RSUP Dr. Sardjito/ FK UGM, Yogyakarta
}

\begin{abstract}
Fungsi fusi gen TEL-AML1 dalam leukemogenesis adalah mempengaruhi kunci proses pengaturan, termasuk kenaikan proses cell-renewal yang tidak terkontrol, menghentikan proliferasi dan diferensiasi yang menyebabkan resistensi terhadap proses apoptosis. Banyak studi menghasilkan data bahwa prognosis pasien leukemia limfoblastik akut (LLA) dengan fusi gena TEL-AML1 masih kontroversi, khususnya prognosis jangka panjang. Banyak penelitian yang menghubungkan adanya fusi gena ini dengan resistensi terhadap kemoterapi, dan lainnya menggunakan minimal residual disease (MRD) untuk melihat respons terhadap pengobatan. Adanya co-existences gena lain bisa memberikan kontribusi terhadap prognosis pasien LLA dengan fusi gen TEL-AML1. Dibutuhkan lebih banyak studi translasional untuk lebih memahami peran fusi gen dalam klinik. Pengetahuan mendasar mekanisme molekular pada leukemia sangat penting, khususnya dalam penanganan pasien. Pemahaman yang lebih baik tentang patogenesis leukemia bisa menghasilkan pengertian dan pengetahuan baru untuk menyusun strategi baru dalam penanganan pasien LLA yang didasarkan kaidah molekular. (Sari Pediatri 2009;10(6):404-9).
\end{abstract}

Kata kunci: leukemia limfoblastik akut, TEL-AML1, prognosis

\footnotetext{
Alamat Korespondensi:

Dr. Sri Mulatsih, Sp.AK. Bagian Ilmu Kesehatan Anak, RSUP Dr. Sardjito Jl. Kesehatan No.1, sekip Utara, Yogyakarta. Fax: +62-274-583745 Phone: +62-274-553142 Email:mulat_wahyudi@yahoo.com
}

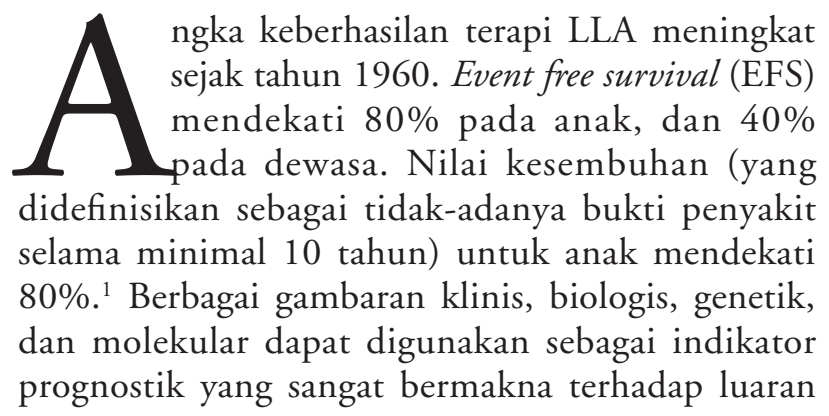


kasus LLA. ${ }^{2}$ Banyak peneliti memfokuskan penelitian di bidang molekular sebagai dasar patogenesis serta penentuan prognosis LLA atau kanker lain.

\section{Genetika molekular LLA}

Gen-gen berperan pada patogenesis terjadinya kanker melalui dua mekanisme umum. Mekanisme pertama adalah gangguan struktur gena yang normal (protooncogene) yang akan menghasilkan gena baru (sebagai oncogene) menghasilkan protein yang berperan pada sel pejamunya untuk menginduksi terjadinya malignansi. Produk protein biasanya berperan pada proliferasi sel, diferensiasi, atau survival. Mekanisme kedua adalah hilang atau tidak aktif gen yang menyandi protein penekan kanker. Gen klas ini dikenal sebagai tumorsuppressor genes atau anti-oncogenes. ${ }^{3}$ Gen-gen yang berperan terhadap terjadinya kanker termasuk LLA dan progresifitasnya dapat dikelompokkan ke dalam beberapa famili didasarkan pada fungsi protein yang disandi. Famili yang paling besar terdiri dari gen yang menyandi faktor transkripsi, protein terikat pada regulator gen target dan akan menstimulasi atau menghambat transkripsi. ${ }^{4}$ Famili lain yang penting termasuk gen yang menyandi proteinkinase, protein yang berperan pada program kematian sel (apoptosis), dan protein-protein dengan fungsi sebagai tumor suppressor, apabila hilang akan memberikan kontribusi terhadap tumorigenesis. ${ }^{5}$

Gangguan pada anggota famili gen spesifik dihubungkan dengan tipe leukemia. Gen leukemogenic terjadi karena gen normal mengalami mutasi, fusi pada

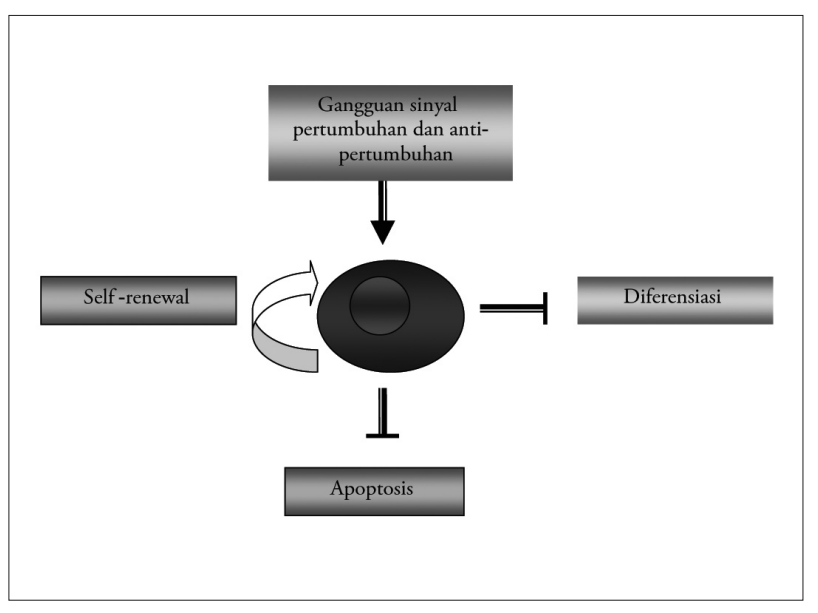

Gambar 1a. Transformasi leukemogenik ${ }^{7}$ gen lain, rearrangement, atau hilang. Proto-oncogen yang berperan pada kontrol proliferasi atau survival akan berubah menjadi oncogen yang menginduksi kanker sebagai akibat fusi gen ke gena lainnya atau mutasi. Fusi atau mutasi akan menghasilkan gangguan regulasi ekpresi gen atau produk gen yang abnormal sehingga akan menyebabkan proliferasi atau survival yang abnormal sel pejamu. Hal ini merupakan step awal dari evolusi leukemia. Tumor-suppressor genes bisa mengalami disrupsi karena mutasi, rearrangments, atau delesi. Hasilnya adalah produk gen tumor-suppressor genes hilang, yang akan berakibat terjadi proliferasi atau survival yang tidak normal. Hal ini sering sebagai kejadian sekunder yang menghasilkan bentuk yang lebih agresif leukemia. ${ }^{3}$

Beberapa gangguan gen dapat ditunjukkan secara mikroskopik sebagai perubahan segmen kromosom gen tersebut berada, dan abnormalitas kromosom pada leukemia sering digunakan sebagai petanda perubahan struktur genetika. Beberapa abnormalitas lain dapat diditeksi hanya dengan analisis molekular karena segmen DNA yang mengalami rearranged, hilang, atau mutasi tidak terlihat secara mikroskopik. ${ }^{6}$

\section{Peran TEL-AML1 dalam leukemogenesis}

Fusi gen TEL-AML1 menyebabkan peningkatan secara tidak terkendali kapasitas perbanyakan diri (self-renewe), kegagalan kontrol proliferasi normal, terhalanginya diferensiasi, dan terjadi resistensi terhadap sinyal kematian (apoptosis) sel hematopoeisi (Gambar 1a). Alur umum target transformasi sel hematopoeitik

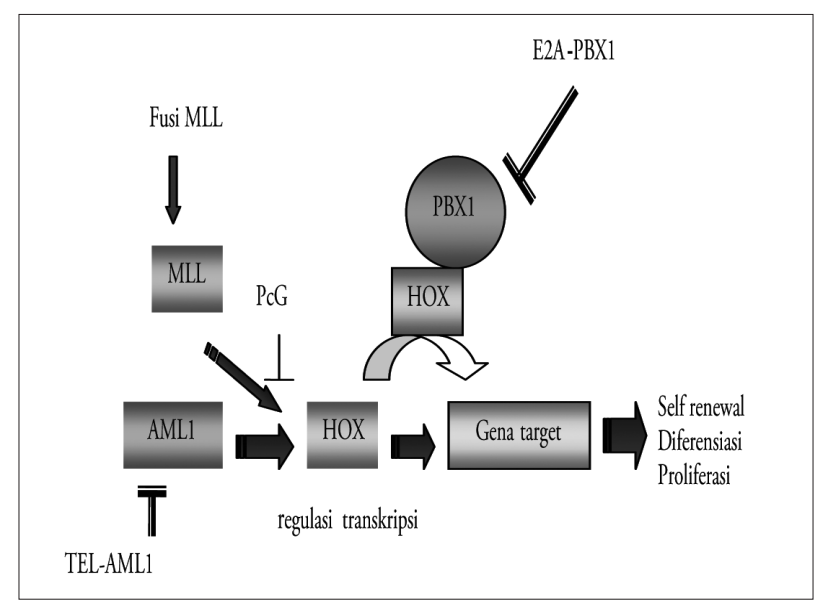

Gambar1b. Mekanisme TEL-AML1 dalam leukemogensis ${ }^{7}$ 
pada patogenesis LLA adalah hasil translokasi faktor transkripsi, seperti fusi protein mixed-lineage leukemia (MLL), translocation-ETS-leukemia (TEL-AML1), dan a helix-loop-helix protein-pre-B-cell transforming (E2APBX1), yang merupakan suatu kaskade yang dimediasi oleh gen homeobox (HOX). Fungsi kompleks faktor transkripsi AML1-CBF $\beta$ (AML1) baik secara langsung maupun tidak langsung meregulasi transkripsi anggota khusus dari family gen HOX. Protein MLL dibutuhkan untuk menjaga transkripsi ini, sedangkan anggota protein polycomb group (PcG) berfungsi menekan transkripsi gena HOX. Protein HOX, kemudian bekerjasama dengan kofaktor, termasuk protein PBX1, untuk menginduksi transkripsi gen target, yang produknya akan mempengaruhi self-renewal, proliferasi, dan diferensiasi sel stem hematopoeitik, termasuk progenitornya (Gambar 1b).

\section{Mekanisme penekanan transkripsi oleh TEL- AML1}

Mekanisme penekanan transkripsi oleh TEL-AML1 tampak pada Gambar 2. Panel a memperlihatkan struktur AML1, terdiri dari central runt homology domain (RHD), yang membantu ikatan DNA dan heterodimerisasi dengan $\mathrm{CBF} \beta$, domain transcriptional activation (TA), dan C-terminal asam amino VWRPY (kode asam amino tunggal), yang membantu ikatan pada groucho corepressor. Struktur AML1 terikat pada inti yang mengatur peningkatan pengaturan transkripsi sebagai bentuk heterodimer dengan $\mathrm{CBF} \beta$, dan bersama-sama mereka akan menarik komplek

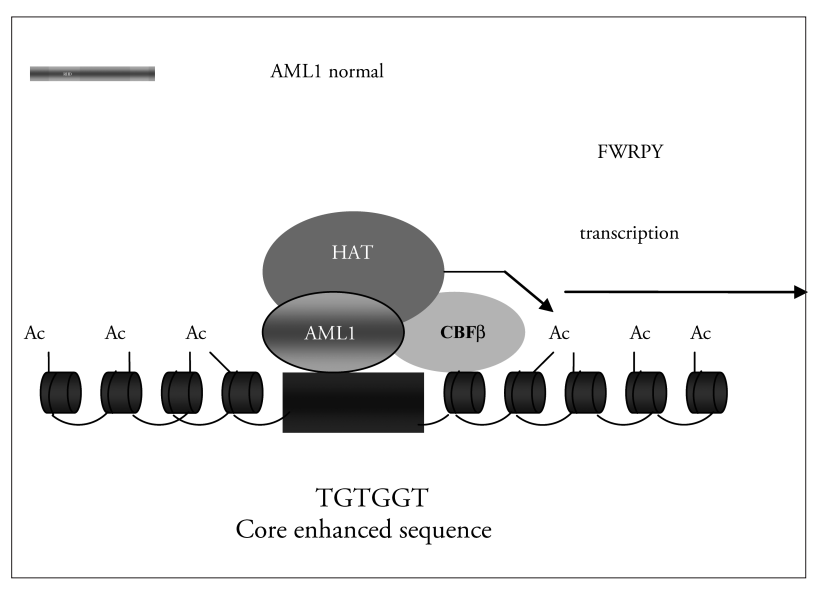

Gambar 2a. Peran AML1 dalam transkripsi ${ }^{7}$ aktifasi transkripsi termasuk disini aktifitas histone acetyltransferase (HAT). Protein HAT acetylate (Ac) lysin tertinggal dalam inti histone, yang membuka struktur kromatin dan menghasilkan aktifasi transkripsi (panah). Panel b memperlihatkan struktur t(12;22) yang menghasilkan protein fusi TEL-AML1, dan domain $N$-terminal helix-loop-helix (HLH) dari TEL mengalami fusi ke protein yang paling dekat dengan AML1. Ujung panah menunjukkan tempat terjadinya fusi antara segmen ini. Protein TEL-AML1 mempunyai kemampuan untuk terikat pada core enhanced sequence dan membentuk heterodimer dengan CBF $\beta$; namun demikian tidak seperti protein AML1 normal, hal ini akan menarik komplek transcriptional corepressor termasuk protein histone deacetylase activity (HDAC), yang melepaskan grup acetyl dari histone, menghasilkan penekanan dan kromatin dari transkripsi yang lebih berdekatan. $^{7}$

\section{Peran TEL-AML1 dalam praktek klinik}

Usia dan jumlah sel darah putih pada saat diagnosis merupakan faktor prognosis tersendiri, namun akhir-akhir ini telah dilakukan penelitian untuk menentukan nilai kemaknaan antara translokasi kromosom dengan prognosis pada pasien LLA T-lineage. Kelainan kromosom, termasuk translokasi khusus pada penelitian bukan acak, sering dijumpai pada sejumlah besar kelompok anak LLA T-lineage, tetapi tidak bermakna sebagai faktor prognosis pada penelitian kohort. ${ }^{8}$ Skrining untuk TEL-AML1 sebagai hasil $\mathrm{t}(12 ; 21)(\mathrm{p} 13 ; \mathrm{q} 22)$ menjadi hal yang

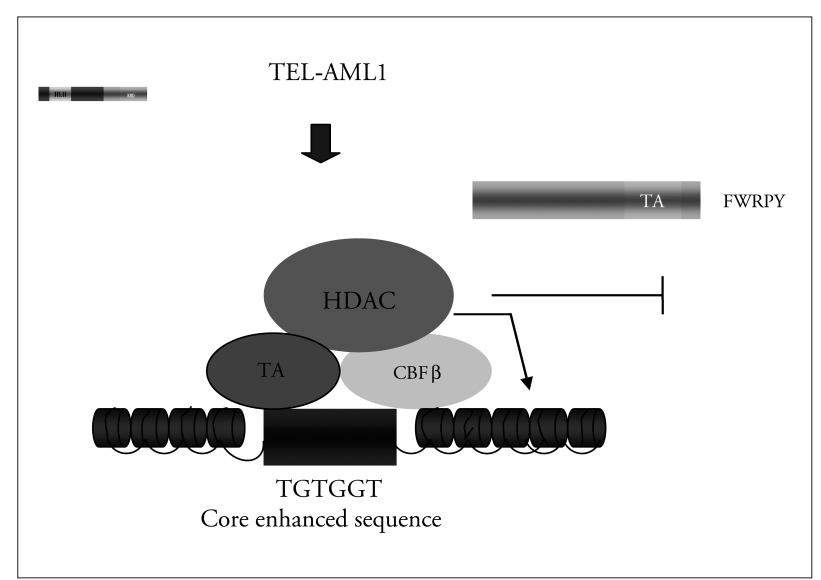

Gambar 2b. Mekanisme penekanan transkripsi oleh TEL$\mathrm{AML}^{7}$ 
rutin dilakukan untuk diagnosis kekambuhan, dan mungkin digunakan sebagai alat untuk stratifikasi pengobatan. ${ }^{9}$ Kontribusi fusi gen ini secara umum belum diketahui, tetapi salah satunya mempengaruhi survival dan apoptosis. ${ }^{10}$

Melalui metode konvensional kasus translokasi $\mathrm{t}(12 ; 21)(\mathrm{p} 13 ; \mathrm{q} 22)$ hanya ditemukan kurang dari $0,05 \%,{ }^{11}$ tetapi dengan metoda fluoresence in situ hybridization (FISH) dan/atau dengan reversetranscriptase polymerase chain reaction (RT PCR) ditemukan pada 16\%-27\% kasus B-ALL. Sebagian besar pasien terdiagnosis saat berusia 2-9 tahun. ${ }^{12}$ Beberapa peneliti mendapatkan hasil bahwa fusi gen berhubungan dengan luaran yang baik. ${ }^{13,14}$ Sekitar 22\% dari seluruh kasus LLA di republik Czech mengalami fusi gen TEL-AML1. Anak yang terdiagnosis dengan fusi gen tersebut sebagian besar usia pra sekolah dengan leukemia tipe sel B, dan mendapat hasil terapi sangat bagus. ${ }^{15}$ Anak-anak yang mempunyai TEL/AML1 positif secara bermakna memiliki kemungkinan kekambuhan yang lebih rendah dibandingkan dengan TEL/AML1 negatif, ${ }^{16,17}$ namun prognosis jangka panjang belum diketahui. Penelitian lain menemukan bahwa frekuensi TEL/ AML1 pada pasien yang mengalami kekambuhan adalah sama dengan yang dilaporkan pada saat diagnosis. Hal ini menunjukkan bahwa TEL/AML1 positif mungkin juga bukan suatu petunjuk atau indikator faktor prognosis yang baik seperti yang dilaporkan sebelumnya. ${ }^{18}$

Beberapa penelitian telah dilakukan untuk mencari hubungan antara fusi gen dengan sensitifitas terhadap kemoterapi. Fusi gen dihubungkan dengan prognosis yang baik karena tingginya sensitifitas selular terhadap L-asparaginase (L-Asp), karena kadar asparagine synthetase (AS) yang rendah. Resistensi terhadap L-asp terjadi sebagai akibat kadar AS dalam sel naik atau kemampuan sel yang resisten secara cepat mengekspresikan gen AS karena paparan L-Asp. Hipotesis tersebut dibantah karena hasil penelitian menunjukkan tidak ada perbedaan antara pasien LLA dengan $\mathrm{t}(12 ; 21)$ positif dan negatif dalam kapasitas meningkatkan regulasi AS, setelah secara in vitro dipaparkan L-Asp. Tidak ada korelasi antara ekspresi AS mRNA dengan sensitifitas terhadap L-Asp. Dapat disimpulkan bahwa sensitifitas anak LLA dengan $\mathrm{t}(12 ; 21)$ terhadap L-Asp tidak berhubungan dengan ekpresi kadar gen AS. Lebih dari itu, hasil berbeda dengan pengetahuan secara umum bahwa sel leukemia secara khusus kekurangan AS dibanding dengan sel normal sumsum tulang maupun sel darah. ${ }^{19}$ Penelitian lain yang melakukan analisis kuantitatif ekspresi AS menunjukkan bahwa kemampuan sel dengan TEL/ AML1[+] menaikkan kadar AS mRNA setelah terapi L-asparaginase lebih tinggi daripada sel leukemia dengan TEL/AML1[-] maupun sel limfoid non leukemik. Diduga bahwa sel dengan TEL/AML1[+] kurang mampu untuk melanjutkan proses siklus sel ke fase $S$ karena tekanan nutrisi disebabkan karena L-asparaginase, disamping itu juga karena kemampuan menaikkan regulasi AS. Secara signifikan ekspresi AS lebih tinggi pada sel leukemia dengan TEL/AML1[+] $(\mathrm{n}=20)$ yang diterapi dibandingkan dengan anak-anak yang belum diketahui fusi genanya $(n=25 ; p=0,0043)$. Tidak ada anak LLA dengan TEL/AML1 [+] dan kadar AS tinggi mengalami relaps, sementara $10 / 15$ pasien dengan kadar AS di bawah median mengalami relaps $(p=0,00028)$. Anak TEL/AML1 [+] dengan kadar AS tinggi dihubungkan dengan prognosis yang lebih baik, kemungkinan karena pengaruh metabolisme pada sel limfoblast. ${ }^{20}$ Sebaliknya, pada LLA sel B resistensi terhadap L-Asp dan risiko relaps dihubungkan dengan ekspresi AS yang tinggi pada TEL-AML-negatif, tetapi tidak pada TEL-AML-positif.. ${ }^{21}$ Penelitian selanjutnya menyimpulkan bahwa meskipun paparan L-Asp menyebabkan ekspresi mRNA AS, kenaikan regulasi ekspresi gen tidak berhubungan dengan respon awal yang jelek terhadap obat tersebut pada anak dengan LLA. ${ }^{22}$

Penelitian lain banyak melihat luaran terapi pada pasien dengan fusi gen melalui penelitian MRD (minimal residual disease) pada waktu induksi atau sesudah terapi induksi. Kasus LLA dengan TELAML1-positif lebih sensitif terhadap terapi induksi dibandingkan TEL-AML1-negatif. Respon awal secara bermakna lebih tinggi pada kelompok dengan TELAML1-positif. Kualitas remisi pada kelompok dengan TEL-AML1-positif sangat bagus, hal ini dibuktikan dengan sangat rendah sampai tidak ada MRD burden dari spesimen sumsum tulang pada akhir induksi. Pasien dengan TEL-AML1-positif juga mempunyai luaran terapi EFS awal yang bagus. Kemungkinan EFS pada 30 bulan adalah $(98,9 \pm 1,0) \%$ pada kelompok TEL-AML1-positif dan $(92,1 \pm 1,5) \%$ grup TELAML1-negatif $(p=0,0001) .{ }^{23}$ Pasien LLA dengan TEL/ AML1-positif memiliki respon induksi lebih baik pada hari ke tigapuluh tiga dibandingkan kelompok pasien LLA lainnya $(p=0,0001)$. Namun demikian, 
empat pasien dengan TEL-AML1 positif mengalami relaps. Dalam analisis Kaplan-Meier mengenai disease free survival terlihat berbeda secara bermakna pada distribusi MRD positif dibanding negatif; log-rank $p=0,0016$. Sehingga disimpulkan, meskipun secara umun TEL-AML1 positif dihubungkan dengan prognosis yang baik, MRD positif pada akhir induksi menunjukkan gambaran prognosis yang buruk. ${ }^{24}$ Penemuan yang berbeda menyebutkan sebagian besar pasien yang mengalami fusi gen TEL-AML1 pada awal diagnosis menunjukkan prognosis yang baik. Adanya fusi gen yang menetap pada MRD, tidak menambah nilai prognostik. ${ }^{25}$

Beberapa penelitian menyebutkan luaran terapi dari pasien dengan fusi gen TEL-AML1 sangat dipengaruhi oleh ekspresi gen lain yang menyertai. Sebagian besar terjadi delesi secara submikroskopik pada regio 5' dari titik patahan AML1. 26,27,28 Kelainan lain adalah delesi TEL, trisomi, dan tetrasomi 21 dan double fusi gena TEL-AML1. ${ }^{28}$ Perubahan lima proses biologi yaitu deferensiasi sel, proliferasi sel, apoptosis, motilitas sel, dan respon terhadap gangguan dapat diidentifikasi berdasarkan ekpresi 14 gen yang berhubungan dengan proses tersebut. ${ }^{29}$ Dari beberapa penelitian yang telah dibahas disimpulkan masih banyak hasil yang berbeda mengenai pengaruh fusi gen TEL-AML1 terhadap luaran terapi pasien LLA anak. Masih diperlukan penelitian lanjutan dari berbagai segi untuk menunjang pelayanan di klinis.

\section{Kesimpulan}

Petanda molekular bisa berguna untuk indikator prognosis penyakit. Pengetahuan mekanisme molekular pada leukemia mempunyai arti penting pada terapi. Melalui pemahaman mekanisme patogenesis leukemia akan menimbulkan pemikiran strategi baru untuk mengatasi lesi secara molekular. Protein TEL-AML1 merupakan fusi gen yang paling banyak terjadi pada LLA anak dan sebagai faktor independen untuk prognosis yang baik pada LLA, namun sampai sekarang pendapat tersebut masih kontroversi. Pemeriksaan fusi gen sudah sangat diperlukan terutama di negara berkembang, sebagai penunjang diagnosis klinis, dengan harapan pasien akan mendapatkan terapi yang lebih sesuai dalam rangka meningkatkan usia harapan hidup pasien LLA .

\section{Daftar Pustaka}

1. Pui CH, Sandlud JT, Pei D. Results of therapy for acute lymphoblastic leukemia in black and white children. JAMA 2003;290:2001-7.

2. Friedman AM, Weinstein HJ, The Role of Prognostic Features in the Treatment of Childhood Acute Lymphoblastic Leukemia. The Oncologist 2000;5:321328.

3. Cline, M.J. The molecular basis of leukemia (review article). NEJM 2004;330:328-36.

4. Cleary ML. Ongogenic conversion of transcription factors by chromosomal translocation. Cell 1991; 66:1-3.

5. Rubnitz JE, Crist, WM. Molecular genetics of chilhood cancer: Implications for pathogenesis, diagnosis, and treatment. Pediatrics 1997;100:101-08.

6. Korsmeyer SJ. Chromosomal translocations in lymphoid malignancies reveal novel proto-oncogenes. Annu Rev Immunol 1992;10:785-807 (Medline).

7. Pui CH, Evans. Acute lymphoblastic leukemia, Narrator Engl J Med 2004;339:605-15.

8. Heerema NA, Sather HN, Senselm MG, Uckun FM. Frequency and clinical significance of cytogenetic abnormalities in pediatric T-lineage acute lymphoblastic leukemia: a report from the children's cancer group. J of Clin Oncol 1998;16:1270-8.

9. Seeger K, Adams HP, Buchwald D, Henze G. TELAML1 fusion transcript in relapsed childhood acute lymphoblastic leukemia. The Berlin-Frankfurt-Munster Study Group. Blood 1988;91:1716-22.

10. Diakos C, Krapf G, Gerner C, Gruemayer RP. RNAimediated silencing of TEL-AML1 reveals a heat-shock protein-and survivin-dependent mechanism for survival. Blood 2007; 109:2607-10.

11. Brisco MJ, Sykes PJ, Dolman G, Morley AA. Effect of the Philadelphia chromosome on minimal residual disease in acute lymphoblastic leukemia [see comments]. Leukemia 1997;11:1497.

12. Pui CH, Carroll AJ, Raimondi SC, Behm FG. Clinical presentation, karyotypic characterization and treatment outcome of childhood acute lymphoblastic leukemia with a near-haploid or hypodiploid less than 45 line. Blood 1990;75:1170-7.

13. Shurtleft SA, Buijs A, Behm FG, Rubnitz JE, Raimondi SC, Hancock ML. TEL/AML1 fusion resulting from a cryptic $\mathrm{t}(12 ; 21)$ is the most common genetic lesion in pediatric ALL and defines a subgroup of patients with an excellent prognosis. Leukemia 1995;9:1985-9. 
14. Whitehead VM, Vuchich MJ, Lauer SJ. Accumulation of high levels of methotrexate polyglutamates in lymphoblasts from children with hyperdiploid (greater than 50 chromosomes) B-lineage acute lymphoblastic leukemia: a Pediatric oncology group study. Blood 1992;80:1316-23.

15. Zuna. The role of TEL and AML1 genes in the pathogenesis of hematologic malignancies. Cas Lek Cesk 2001;140:131-7.

16. McLean TW, Ringold S, Neuberg D, Stegmaier K, Tantravahi R, Ritz J. TEL/AML-1 dimerizes and is associated with a favorable outcome in childhood acute lymphoblastic leukemia. Blood 1996;88:4252-8.

17. Borkhardt A, Cazzaniga G, Viehmann S, Valsecchi MG, Ludwig WD, Burci L. Incidence and clinical relevance of TEL/AML 1 fusion genes in children with acute lymphoblastic leukemia enrolled in the Germans and Italian multicenter therapy trials. Blood 1997;90: 571-7.

18. Cayuela JM, Baruchel A, Orange C, Madani A, Auclerc MF, Daniel MT. TEL-AML1 fusion RNA as a new target to detect minimal residual disease in pediatric B-cell precursor acute lymphoblastic leukemia. Blood 1996;88:302.

19. Stams WAG, Boer ML, Beverloo HB, Pieters R. Sensitivity to L-asparaginase is not associated with expression levels of asparagine synthetase in $\mathrm{t}(12 ; 21)+$ pediatric ALL. Blood, 2003;101:2743-7.

20. Krejci O, Starkova J, Otova B, Trka J. Upregulation of asparagine synthetase fails to avert cell cycle arrest induced by L-asparaginase in TEL/AML1-positive leukaemic cells. Leukemia 2004;8:434-41.

21. Stams WAG, Den Boer ML, Holleman A, Pieters $\mathrm{R}$. Asparagine synthetase expression is linked with $\mathrm{L}$-asparaginase resistance in TEL-AML1-negative but not TEL-AML1-positive pediatric acute lymphoblastic leukemia. Blood 2005;105:4223-5.
22. Appel LM, Den Boer ML, Meijerink JPP, Veerman AJP, Reniers NCM, Pieters R. Up-regulation of asparagine synthetase expression is not linked to the clinical response to L-asparaginase in pediatric acute lymphoblastic leukemia. Blood 2006;107:4244-9.

23. Uckun FM, Pallisgaard N, Hokland P, Heerema N. Expression of TEL-AML1 fusion transcript and response to induction therapy in standar risk acute lymphoblastic leukemia. Leuk Lymphoma 2001;42:41-56.

24. Madzo J, Zuna J, Muzikova K, Trka J. Slower molecular response to treatment predict poor outcome in patients with TEL/AML1 positive acute lymphoblastic leukemia: prospective real-time quantitative reverse trabscriptase-polymerase chain reaction study. Cancer 2003;97:105-13

25. Mosad E, Hamed HB, Bakry RM, Ezz-Eldin AM, Khalifa NM. Persistence of TEL-AML1 fusion gene as minimal residual disease has no additive prognostic value in CD 10 positive B-acute lymphoblastic leukemia: a FISH study. J Hematol Oncol 2008;1:17

26. Ma SK, Wan TS, Cheuk AT, Chan LC. Characterization of additional gentic events in childhood acute lymphoblastic leukemia with TEL/AML1 gene fusion: a molecular cytogenetic study. Leukemia 2001;15:1442-7.

27. Mikhail FM, Serry KA, Hatem N, Nucifora G. AML1 gene ever-expression in childhood acute lymphoblastic leukemia. Leukemia 2002;16:658-68.

28. Rothman R, Trakhtenbrot L, Bielorai B, Toren A. Co-existensi of multiple subclones in TEL-AML1 at diagnosis of acute lymphoblastic leukaemia in association with submicroscopic deletion of AML1. Br J Haematol 2005;129:491-8.

29. Gandemer V, Rio AG, Tayrac M, Galibert MD. Five distinct biological processes and 14 differentially expressed genes characterize TEL/AML1-positive leukemia. BMC Genomics 2007;8:385. 